\title{
C. L. R. James and the Race/Class Question
}

The twentieth century has witnessed an intensification of the worldwide struggle of black people for freedom from colonialism and race prejudice. This struggle has its roots in the nineteenth century and before. At various stages in this struggle the ranks of black revolutionaries have been augmented by volunteers, as it were, from among the ranks of white liberals and radicals.

One of the most vexing problems, at both the theoretical and practical levels, with which persons involved in this struggle have had to deal, is the question of the relative weights which should be assigned to the rival factors of race and class. In other words, should the struggle be articulated essentially in terms of a racial conflict, or should it rather be viewed as a variant, albeit a special one, of the struggle of oppressed classes? On the one hand, people like Marcus Garvey, though by no means oblivious of the class distinctions affecting black people, have nevertheless argued (in Garvey's case with phenomenal success) for the primacy of race, and have therefore emphasized the Black Nationalist aspects of the struggle. On the other hand, we have the example of a host of black communists, Trotskyites, and other Marxists who reached political maturity in the 1920 s and 1930 s, and who were firm advocates of the primacy of the class struggle as a vehicle for black liberation. These black Marxists felt very keenly the racial injustices meted out to their people, but nevertheless frowned, in varying degrees, upon what they characterized as the 'petit-bourgeois nationalism' of people like Garvey. This group did not necessarily minimize the race factor. Indeed, the Communist Party of the United States had by 1928 come to the conclusion (on the direction of Moscow) that Afro-Americans exhibited the attributes of an oppressed nation, while Leon Trotsky, at least as early as 1933, seemed to be moving towards a similar position. ${ }^{1}$

\section{BIOGRAPHICAL SKETCH}

Among the more important black Marxists engaged in the worldwide struggle of oppressed black people from the 1930s onwards was C. L. R. James, ${ }^{2}$ and his approach to this problem, though not necessarily identical with anybody else's, nevertheless provides an insightful case study of the way in which a black Marxist could attempt to resolve the problem.

TONY MARTTN is Assistant Professor of History at the University of Michigan-Flint. Race, XIV, 2 (1972) 
James was born in Trinidad in 1901, one year after the epochal Pan-African Conference held in London had bequeathed the term 'panAfricanism' to the worldwide struggle of black peoples. ${ }^{3}$ This conference had been convened by another Trinidadian, Henry Sylvester-Williams, and had been attended by, among other people, W. E. B. DuBois. In 1932, after some political and literary activity in Trinidad, James moved to England, where his predilection for left-wing politics brought him to the Trotskyite movement. By 1937, with the publication of his World Revolution, $1917-1936^{4}$ he had already established himself as a leading theoretician of the movement. His interests were catholic, however, and his output prolific. For in this period he also produced works of fiction ranging from plays to novels, was a cricket correspondent for the Manchester Guardian, and wrote books on black history, including his magnum opus, The Black Jacobins. ${ }^{5}$

1938 found him in the United States engaged in a lecture tour and studying the condition of Afro-American communities. In 1939 he engaged in discussions with Leon Trotsky at Coyoacan, Mexico, on the 'Negro question', to use the terminology of the age. ${ }^{6}$ This American period lasted until 1952, when James was expelled from the United States, a victim of the McCarthyite period of communist-hunting.? During this first American period (for he was to return later) James participated actively, among other things, in organizational work among sharecroppers in south-east Missouri and among workers in Detroit and elsewhere.

The year of James's arrival in the United States (1938) was the same in which the Trotskyite Socialist Workers Party (S.W.P.) was formed. James's reputation had apparently preceded him, for he seems to have assumed a position of pre-eminence in American Trotskyite circles right from the beginning. The following account of his role in the 1939 discussions between the S.W.P. and Trotsky gives some indication of his importance:

The principal figure in the delegation that visited [Trotsky] was J. R. Johnson [James's political pseudonym], a revolutionary black intellectual from one of the British colonies and a member of the Fourth International. Johnson had been living in the United States for the previous six months, acquainting himself, among other things, with the state of the American Negro community. ${ }^{8}$

In 1940 James was one of a minority which split from the S.W.P. and formed the Workers Party. Shortly thereafter, James and a few of his disciples coalesced into a faction within the Workers Party. A publication of this faction in 1947 explained that 'the Johnson-Forest tendency', as it became known, 'became conscious of itself early in 1941 in the discussion of the Russian question'. ${ }^{9}$ In 1947 the Johnson-Forest tendency re-entered the S.W.P., where it remained until $1951 .{ }^{10}$

James's deportation from the United States induced a sojourn in England until 1958, when he returned to Trinidad, at the request of Eric Williams, the island's premier, to edit The Nation, organ of Williams's Peoples National Movement (P.N.M.). He also became secretary of the West Indian Federal Labour Party, ruling party of the short-lived Federation of the West Indies. Ideological and other differences between James and members of the P.N.M.'s hierarchy caused him to resign his editorship of The Nation in 1960 and to return to England a couple of year later. 
In 1965 James returned to Trinidad in his role as a cricket reporter to cover an international series, whereupon he was placed under what amounted to house arrest by the Williams government. ${ }^{11}$ James retaliated by helping organize a Workers and Farmers Party, which, however, did not fare well in the general election of 1966. Another brief sojourn in England followed.

For the last two or three years James has been a university professor at black colleges in the United States. He was recently (1971) awarded an honorary doctorate by the University of the West Indies.

James's importance for the history of the Pan-African struggle of the last four decades proceeds largely from the fact that he has worked closely with, and often influenced, many of the persons who have led that struggle in various parts of the world. First among these was George Padmore, the Trinidadian who, in 1928, became head of the Negro Bureau of the Red International of Labour Unions (Profintern), whose headquarters were in Moscow. They were co-founders in 1937 of the International African Service Bureau, of whose organ, International African Opinion, James was editor. ${ }^{12}$ Previous to this they had collaborated in an organization formed by James known as The International African Friends of Ethiopia. In fact, their friendship dated back to their boyhood days in Trinidad. ${ }^{13}$

Padmore is one of the most important figures in the history of the Pan-African idea. Together with Kwame Nkrumah, first president of independent Ghana, he organized the fifth Pan-African Congress held in Manchester in 1945. This conference is generally considered to be one of the most important events in the history of Pan-Africanism. Padmore's last contribution to the struggle was as Nkrumah's adviser on African affairs. He died in 1959.

James's role in the evolution of the Pan-African idea can be seen equally well in his association with Kwame Nkrumah himself. James first came into contact with Nkrumah during the latter's student days in the United States, and Nkrumah, in his autobiography, duly paid tribute to James for having initiated him into the intricacies of how an underground movement worked. ${ }^{14}$

It was James also who provided Nkrumah with the letter of introduction to George Padmore. According to James, Nkrumah at that point still suffered from certain ideological shortcomings-'he used to talk a lot about imperialism and Leninism and export of capital, and he used to talk a lot of nonsense'. ${ }^{15}$ The letter nevertheless stated, 'George, this young man is coming to you. He is not very bright, but nevertheless do what you can for him because he's determined to throw the Europeans out of Africa.' ${ }^{16}$

In 1967 James became very interested in the political development of Stokely Carmichael and was moved to proffer much unsolicited advice to this young Pan-Africanist. ${ }^{17}$ It is interesting to note that Carmichael, like James and Padmore before him, was associated with Nkrumah prior to the latter's death. They both lived in Guinea.

James's influence, of course, has not been limited to persons who were outstanding advocates of Pan-Africanism. Thus Jomo Kenyatta was also a member of the International African Service Bureau, and Eric Williams regarded him as something of a mentor before their break in $1960 .^{18}$ In addition, generations of black students have treated him with veneration 
and have enlisted his support and advice for all manner of revolutionary causes. ${ }^{19}$

\section{THE RACE/CLASS QUESTION}

More than most other Pan-African revolutionaries, James has been a Marxist first and foremost, and his ideas on issues relevant to the international black struggle have been developed within the general framework of his Marxist theories. In fact, his whole Pan-Africanist involvement may justifiably be viewed as no more than one aspect (though a very important aspect) of his Marxist activities. And unlike most of the other leading Pan-African ideologists of the last few decades, his prolific writings contain a large proportion of material on Marxist theory, in which aspects of the Pan-African struggle do not appear or appear only peripherally. ${ }^{20}$ This circumstance does not, of course, diminish his contribution to the worldwide political development of black peoples.

James's independent interpretations of Marxist theory took organizational form, as has been seen, through the Johnson-Forest tendency. And among the theoretical principles which were central to the tendency were the rejection of the idea of Stalinist Russia as a workers' state, the rejection of Lenin's theory of the vanguard party as correct for the changed circumstances of the post-1917 world, and support for the control of industry and politics by workers (as manifested by the workers' councils which emerged during the Hungarian Revolution of 1956) as the basis of the future ideal state. The Johnson-Forest tendency, in a word, set out to update Marx and Lenin and correct Trotsky, while attempting nevertheless to remain true to the essentials of Marxism-Leninism.

As a Marxist, quite naturally, James had little difficulty making his mind up on the question of the ascendancy of class over race. Even when accepting the applicability of Lenin's ideas on national minorities to the movement for self-determination among Afro-Americans, for example, or when appearing to condone the rhetoric of Black Power, he has never deviated from his view that race is subordinate to class.

This is illustrated in practically everything he ever wrote on the race question. His magnum opus, The Black Jacobins (a history of the Haitian Revolution) was thus conceived not so much as the triumph of black slaves over their white oppressors, as an 'analysis of a revolution for selfdetermination in a colonial territory'. ${ }^{21}$ It constituted, in his opinion, 'a book of general historical interest written especially with a view to the elucidation of the African revolution. The point about that book is that it kept an even balance between general history and Marxist policy. ${ }^{22}$ His preparation for writing the book included a study of Lenin. ${ }^{23}$ It is not surprising to find in this work, therefore, a clear summation of his theory of race, from which he has never seriously deviated: 'The race question is subsidiary to the class question in politics, and to think of imperialism in terms of race is disastrous. But to neglect the racial factor as merely incidental [is] an error only less grave than to make it fundamental. ${ }^{24}$ Indeed, James sometimes appears to be possessed of a certain detachment from any personal emotional involvement in the racial injustice he thunders against. His resolution on the 'Negro Problem' to the Socialist Workers Party convention of 1948 gives an inkling of this tendency. This resolution contained an excellent historical analysis of the black experience in America. The concluding sentence reads: 
Anyone who knows them, who knows their history, is able to talk to them intimately, watches them at their own theatres, watches them at their dances, watches them in their churches, reads their press with a discerning eye, must recognize that although their social force may not be able to compare with the social force of a corresponding number of organized workers, the hatred of bourgeois society and the readiness to destroy it when the opportunity should present itself, rests among them to a degree greater than in any other section of the population in the United States. ${ }^{25}$

It is difficult to find in this coldly incisive analysis the sense of personal hurt against personally experienced racial injustice that one finds in Fanon, ${ }^{26}$ or that characterized Nkrumah's experience in the United States, ${ }^{27}$ or, strange to say, that is sometimes expressed in the work of Eric Williams, or that is inherent in the invective of a Stokely Carmichael. And one just cannot conceive of James ever being affected to the extent of Garvey, who is said to have been moved to tears after viewing a parade of the decimated ranks of black veterans returning to Harlem after World War One. ${ }^{28}$ Garvey's empathy with the vain sacrifices of these black soldiers was complete.

This unusual ability of James to suppress any sense of personal bitterness on the race question seems even to have antedated his conversion to Marxism. For in reminiscences of his adolescence he mentions a case of racial discrimination meted out to him personally, but which he seems to have dismissed sans rancour. He had attempted to enlist in the Merchants and Planters Regiment (white) rather than in the white-officered British West Indies Regiment which was set aside for black West Indian patriots during World War One. James explained:

The rumour was, and the facts seemed to show, that the merchants selected only white or brown people. But though I was dark, I was widely known as a coming cricketer and I kept goal for the college teams in the first-class football league. I was tall and very fit ... I went down to the office where one of the big merchants, perhaps the biggest of all, examined the would-be warriors . . . . When my turn came I walked to his desk. He took one look at me, saw my dark skin, and shaking his head vigorously, motioned me violently away.

What matters is that I was not unduly disturbed . . . It didn't hurt for long because for so many years these crude intrusions from the world which surrounded us had been excluded. I had not even been wounded, for no scar was left. ${ }^{29}$

The 'crude intrusions from the world' outside had been excluded by the atmosphere at Queen's Royal College in Trinidad which he attended, and which he called 'our little Eden' ${ }^{30}$ At this time the teaching staff was composed almost entirely of English graduates of Oxford and Cambridge, and the college itself was still largely the school for sons of white civil servants. James had entered it by winning one of the few competitive scholarships awarded annually. His 'little Eden' contrasts markedly with the recorded experiences of a later generation of black students who passed through similar schools in the West Indies at a time when race relations can be presumed to have improved, but who described anything but a 'little Eden' ${ }^{31}$

With this attitude towards race then, proceeding from his Marxism and apparently reinforced by his adolescent experiences, James, like most other Marxists involved in the race question, enthusiastically welcomed the breakthrough in race relations which seemed to be heralded by the appearance of the Congress of Industrial Organizations in the mid-1930s. 
Here, for once, it seemed that his ideas on the proletarian and the race questions, as well as his belief in the spontaneity of the masses as superior to the dictates of 'vanguard parties', were actually being demonstrated in practice. For the workers had,

seized capitalist property by force. Secondly, they opened their gates to Negroes, since the Civil War the biggest action on this running sore of American society. Thirdly, in general they acted in a manner that showed the revolutionary fervour that was moving in them, ... The specific American readiness for action without theory is here seen at its best. ${ }^{32}$

It may be for these reasons that he could ascribe the apparent slackening of black nationalist activity in the late 1930s to the black man's newlyfound 'opportunity to fight with the organized workers and to gain something'. ${ }^{33}$ The decay and bureaucratization of the C.I.O. only served to reinforce his animosity towards union leaders, to whom he is as opposed as to the leaders of the Soviet Union.

His enthusiasm for the C.I.O. seems to have led him to extreme lengths to demonstrate the affinity between white and black workers. Thus in the early 1940s in a propaganda pamphlet published by a C.I.O. affiliate we find him making the dubious claim, in a section headed 'To the White Workers Especially', that, 'There was a lynching in Sikeston the other day and the Negroes are bitter about it, but that lynching was a landlord's trick to divide us. All our brothers in Sikeston are ready to join with you in the most important thing before you and us-the fight for $30 \mathrm{c}$ an hour., ${ }^{34}$

James's enthusiasm for the C.I.O. is further illuminated by reference to his very orthodox Marxist position on the dependence of the black revolution on the success of the wider proletarian struggle. He stated this argument very clearly in 1960 to an audience in Trinidad:

The great problem of the United States, with all due respect to the colour of the majority of my audience, is not the Negro Question. (If this question of the workers' independent political organization were solved the Negro Question would be solved. As long as this is not solved the Negro Question will never be solved). ${ }^{35}$

And two decades before this he had proposed a historical framework to substantiate his case during his dicussions with Trotsky in Mexico:

1. The study of Negro history and historic propaganda should be:

(a) Emancipation of Negroes in San Domingo linked with the French Revolution.

(b) Emancipation of the slaves in the British Empire linked with the British Reform Bill of 1832 .

(c) Emancipation of the Negroes in the United States linked with the Civil War in America. This leads easily up to the conclusion that the emancipation of the Negro in the United States and abroad is linked with the emancipation of the white working class.

(d) The economic roots of racial discrimination.

(e) Fascism.

(f) The necessity for self-determination for Negro peoples in Africa and a similar policy in China, India, etc. ${ }^{36}$

In presenting this argument James has sometimes shifted the emphasis in a manner which is barely perceptible but very significant. On these 
occasions he seems to view the white proletariat, not necessarily as ready and willing to join hands with the oppressed black masses, but as the means of heightening the contradictions within white society, contradictions which black people can use to their advantage. In this argument he seems to be hinting around the periphery of what Marcus Garvey characteristically asserted with a minimum of circumspection: 'Negroes have no right with white peoples' fights or quarrels, except like the humble, hungry, meagre dog, to run off with the bone when both contestants drop it, being sure to separate himself from the big, well-fed dogs, by a good distance, otherwise to be overtaken, and then completely outdone.'37

Both these lines of thought-that black people should unite with white workers, and that black people should capitalize on the contradictions within white society, are usually found together in James's writings and flow from the same analysis. He does not normally consider them opposed to each other but complementary. Both streams can easily be discerned, for example, in his 1939 conversations with Trotsky and in his 1948 resolution on the race question. They are seen even more clearly in a document written probably only a few months after that 1939 meeting. In this document James looks forward to the second civil war in America which will complete the emancipation of black people:

Sooner or later the workers and farmers of America, who are now fighting against the landlords and capitalists in unions, on the WPA, in struggles for better relief, will ultimately be driven to the same civil war that we have seen take place in country after country during the last 25 years. A Negro therefore who is looking at the political situation, not as it appears on the surface, but is seeing into the reality of the struggle between the classes, can have confidence in the future. He will realize that all white America is not solid. There is a tremendous division, a great split opening up. We can already see the signs of it very clearly. And as this struggle approaches and then actually flares out into the inevitable civil war, Negroes can be certain that many white workers and farmers who today are prejudiced will seek Negro assistance in the same way that Lincoln did when he fought the South. Negroes in the last civil war made one great step forward, and so, in this coming civil war, the worker's war, Negroes have a great chance to complete their long journey to full freedom. $^{38}$

This statement leads on naturally to an examination of one of the most important aspects of James's position on the race/class question. For within the general framework of the unity of struggle between white workers and black toilers, he recognized, and in fact stressed, the independent validity of the black struggle. We have a unique opportunity to see him clarifying this position in the record of his conversations with Trotsky in 1939.

For this meeting James prepared a preliminary statement which served as a basis for the discussion. In it he postulated that 'the Negro, fortunately for socialism, does not want self-determination', but nevertheless 'if he wanted self-determination, then however reactionary it might be in every other respect, it would be the business of the revolutionary party to raise that slogan.' (Emphasis in the original). He went on to develop this argument during the conversation:

The white workers have centuries of prejudice to overcome, but at the present time many of them are working with the Negroes in the Southern sharecroppers' 
union and with the rise of the struggle there is every possibility that they will be able to overcome their agelong prejudices. But for us to propose that the Negro have this black state for himself is asking too much from the white workers, especially when the Negro himself is not making the same demand. ${ }^{39}$

He sealed his arguments against advocating self-determination by alleging that the black population in the United States lacked the 'tradition of language, literature and history to add to the economic and political oppression'.40

To these arguments Trotsky and another participant objected. They could see nothing inherently reactionary in self-determination and they disagreed that the Afro-American lacked the necessary cultural and historical basis to form a separate nation. Trotsky also insisted (in opposition to James) that Garvey's movement represented a sublimated desire for self-determination. Accord was easily reached by the parties and James shortly afterwards drafted a resolution on 'The SWP and Negro Work' which recognized the validity of 'black chauvinism' in view of the betrayal of black people by white Democrats, Republicans, communists, and others, and condemned "white American chauvinism, the expression of racial domination', as 'reactionary'. ${ }^{41}$ The resolution went on to propose the organization of a 'Negro mass organization' on the initiative of black S.W.P. members. James's authorship of the resolution showed clearly in the proviso that such an organization would not invalidate the necessary struggle for unity of both black and white workers. But that road is not likely to be a broad highway. ${ }^{\prime 2}$

This resolution of 1939 remains a true summation of James's main ideas on the position of race in the revolutionary struggle, and he has remained true to it even to the extent of terminating political alliances rather than compromise on it. In 1947, for example, we find included in the case of the Johnson-Forest tendency against the Workers Party, the latter's abandonment of the 1939 position:

One of Trotsky's greatest contributions to the American party was his insistence for over ten years on the need to adapt the Leninist policy on the national question to the Negro problem in the United States. The American comrades resisted or gave an acquiescence which was worse than resistance. Finally, in 1939 under Trotsky's careful supervision a policy was adopted. As if by reflex action no sooner did the minority split than Coolidge attacked the position adopted almost unanimously in the SWP. Stage by stage the position was abandoned, accompanied by the most ignorant and unscrupulous attacks upon the whole past of the discussions in our movement and our political tradition. The Minority fought in vain to stem this tide. The result is that the party today is in a mass of unbelievable confusion on a question which in the United States stands second only to the basic conflict between the bourgeoisie and the proletariat itself, besides being of worldwide importance. ${ }^{43}$

And immediately he abandoned the Workers Party to rejoin the S.W.P. he presented his 1948 resolution which was an amplified restatement of the 1939 position. $^{44}$

Whereas in 1947 he had attacked the Workers Party for ignoring the independent aspect of the race question, in 1961 his own small organization split over the opposite problem, namely that of giving too much weight to race viv-à-vis class. Some members of the organization, in the words of a member who adhered to James's view, had failed 'to link up the 
revolutionary struggle of the Negroes with that of the working class'. This comrade went on-'To stress only the race angle is to surrender the paper's treatment of the question either to the liberals, on the one hand, who see only the extension of Rights, or the Muslims, on the other hand, who see only the extension of Race.' ${ }^{45}$

Round about 1967 James became very impressed by the intensification of the black struggle for liberation as exemplified by the advocates of Black Power. And his enthusiasm for the young militants who appeared on the scene on occasion infused his sentiments with expressions which were almost unlike him. On one occasion, for example, he informed a youthful audience, in the midst of an approving analysis of $H$. 'Rap' Brown, that 'the singlemindedness, the determination to fight to the death if need be, which now permeates the Negro movement, will not be corrupted, modified, or in any way twisted from its all-embracing purpose by white do-gooders and well-wishers.' ${ }^{46}$

He felt the need to qualify this statement, however, for he hastened to explain that this was not racism but politics. Furthermore, he assured his audience, racism was on the decline in the United States anyway. What was on the increase was black people fighting the police, rather than white people fighting black people. This tendency to consign racism to a premature demise was evident as early as 1939, and is a trait which crops up from time to time in the works of Marxists.

The case of James, then, though not necessarily identical with any other, nevertheless provides an interesting case study of one black Marxist's quest for a reconciliation of the class and race struggles. The primacy of class in James is, of course, common to all Marxists. His impatience with those who emphasize the race aspect at the expense of a class analysis, is also typical. Yet several black Marxists, including his friend George Padmore, have from time to time actually broken off their communist affiliations (though this has not always been followed by a rejection of Marxism) because as black men they found themselves irresistibly attracted to the cause of black solidarity, even at the expense of their Marxist training. Padmore was specifically charged with this offence (in his case deserting a class position to engage in 'petit-bourgeois' pro-Liberia activities) upon his expulsion from among the ranks of communists. James has been less affected by this attraction than most, no doubt because he has always been a much more thorough-going Marxist than many, black or white. Yet his record of participation in black causes seems to suggest that for him, at least, there has been no insurmountable contradiction.

\section{References}

${ }^{1}$ See George Breitman, ed., Leon Trotsky on Black Nationalism and Self-Determination (New York, Merit Publishers, 1967), passim.

2 Many of James's works contain biographical information. In addition, a biographical sketch can be found in Martin Glaberman's introduction to the C. L. R. James Special Issue of Radical America (Vol. IV, No. 4, May 1970). I am grateful to Mr. Glaberman for allowing me to obtain copies of publications by James which are out of print and difficult to come by, and for not appearing to be importuned by my many questions. Mr. Glaberman is a long-time political associate of Mr. James.

${ }^{3}$ Since the famous Fifth Pan-African Congress held at Manchester in 1945, the term 'Pan-Africanism' has increasingly been applied to the question of political unity on the African continent. Its original meaning (which included both the above usage and the idea of a community of interest among African people all over the world) still enjoys wide currency. See, e.g., Stokely Carmichael, 'We Are All Africans', The Black 
Scholar (Vol. I, No. 7, 1970), pp. 15-19. James himself reflected this resurgence of the original Pan-African outlook when he reprinted his $A$ History of Negro Protest (London, 1936) as A History of Pan-African Revolt (Washington, D.C., Drum and Spear Press, 1969).

${ }_{4}^{4}$ C. L. R. James, World Revolution, 1917-1936-The Rise and Fall of the Communist International (London, Secker and Warburg, 1937). 1938).

${ }^{5}$ C. L. R. James, The Black Jacobins (New York, Vintage, 1963; first published

${ }^{6}$ Leon Trotsky on Black Nationalism, passim.

7 James's own account of the tribulations surrounding his deportation can be found in his Mariners, Renegades and Castaways-The Story of Herman Melville and the World We Live In (New York, published by C. L. R. James, 1953).

${ }^{8}$ Leon Trotsky on Black Nationalism, p. 21.

' Johnson-Forest Tendency, Balance Sheet: The Workers Party and the JohnsonForest Tendency (n.p., pub. by Johnson-Forest Tendency, August 1947), p. 8.

${ }_{10}$ The date of re-entry into the S.W.P. is erroneously given as 1951 in Ivar Oxaal, Black Intellectuals Come to Power, q.v. for much biographical information on James (Cambridge, Mass., Schenkman, 1968), p. 77 . The 1951 date of final exit is given by James himself in J. R. Johnson, Letter on Organization (Detroit, Facing Reality Publishing Committee, n.d.), p. 3.

${ }_{11}$ See C. L. R. James, 'Dr. Williams's Trinidad: An Attack', Venture (January 1966).

${ }^{12}$ C. L. R. James, 'African Development', Speak Out, journal of the Facing Reality Publishing Committee (Vol. II, No. 4 April 1969), p. 4. The date given here for the formation of the Bureau is 1935. The date usually given is 1937. Also, the formation of the I.A.S.B. is usually credited solely to Padmore. For more on the relationship between Padmore and James, see C. L. R. James, 'Document: C. L. R. James on the Origins', Radical America (Vol. II, No. 4 July-August 1968), pp. 24-7, and J. R. Hooker, Black Revolutionary: George Padmore's Path from Communism to Pan-Africanism (London, Pall Mall, 1967), passim.

13 'Document: C. L. R. James on the Origins', op. cit., p. 24.

${ }_{14}$ Kwame Nkrumah, Ghana (London, Nelson, 1959), p. 36.

15 'Document: C. L. R. James on the Origins', op. cit., p. 26.

${ }^{16}$ Ibid.

${ }^{17}$ See C. L. R. James, Black Power: Its Past, Today, and the Way Ahead (Detroit, Facing Reality, 1968), passim; and Facing Reality Publishing Committee, The Gathering Forces (Detroit, Facing Reality, 1967), pp. 65-7. This was a draft of a statement to celebrate the fiftieth anniversary of the October Socialist Revolution in the Soviet Union. It was a collective effort. Mr. Glaberman indicated to me the passages written by James.

${ }^{18}$ Williams, in his autobiography, says he gave up an opportunity to visit Nigeria in order to confer with James in London in 1956 on his party's draft programme and Trinidad's draft constitution. Padmore and West Indian economist W. Arthur Lewis also participated in these discussions. See Eric Williams, Inward Hunger (London, Deutsch, 1969), p. 143.

${ }^{19}$ Black students in London organized a 'C. L. R. James School' recently-Bumbo (journal of the West Indian Students Union in London, n.p., n.d., c. April 1970); a recent case of James's participation in protest activities of black students in London can be found in the Trinidad Guardian (18 August 1967), p. 1. The occasion was the banning of Stokely Carmichael by the British and Trinidad governments.

20 James's major works on Marxist theory are World Revolution; State Capitalism and World Revolution (Detroit, Facing Reality, 1969, first pub. 1950); and Facing Reality (Detroit, Correspondence, 1958).

21 Black Power, p. 12.

22 J. R. Johnson, Letters on Organization (Detroit, Facing Reality, 1963), p. 14.

${ }^{23}$ Black Power, p. 12.

24 Black Pacobins, p. 283.

${ }^{25}$ C. L. R. James, "The Revolutionary Solution to the Negro Problem in the United States', Radical America (Vol. IV, No. 4, May 1970), p. 18. The date given for the resolution here is 1947. James gives it as 1948 in C. L. R. James, Perspectives and Proposals (Detroit, Facing Reality, 1966), p. 31.

${ }^{26}$ Especially in Black Skin, White Masks (New York, Grove Press, 1967).

${ }^{27}$ E.g. in Ghana.

28 J. Saunders Redding, The Lonesome Road (New York, Doubleday, 1958), p. 227.

${ }^{29}$ C. L. R. James, Beyond A Boundary (London, Hutchinson, 1963), p. 40.

${ }^{30}$ Ibid., p. 39.

${ }^{\text {a1 }}$ See, e.g., Elliott Bastien, 'The Weary Road to Whiteness and the Hasty Retreat into Nationalism', in Henri Tajfel and John Dawson, eds., Disappointed Guests (London, Oxford University Press for the Institute of Race Relations, 1965), p. 44; Austin Clarke, 'Harrison College and Me', New World Quarterly (Vol. III, Nos. 1 and 2, Barbados Independence Issue, Dead Season 1966 and Croptime 1967), pp, 31-5. 
32 J. R. Johnson, Marxism and the Intellectuals (Detroit, Facing Reality, 1962), p. 14.

${ }^{33}$ Conversation with Trotsky in Leon Trotsky on Black Nationalism, p. 26.

34 J. R. Johnson, Down With Starvation Wages in South-East Missouri (Local 313, UCAPAWA-CIO, n.d.), p. 5.

${ }^{36}$ C. L. R. James, Modern Politics (Port-of-Spain, P. N. M. Publishing Company, 1960), p. 45.

${ }^{36}$ Leon Trotsky on Black Nationalism, p. 38.

${ }^{37}$ Marcus Garvey, 'The Negro, Communism, Trade Unionism and His [?] Friend', in Amy Jacques Garvey, ed., The Philosophy and Opinions of Marcus Garvey (London, Frank Cass, 1967), Vol. II, p. 70.

${ }^{38}$ J. R. Johnson, Why Negroes Should Oppose the War (New York, Pioneer Publishers, for the S.W.P. and the Young Peoples Socialist League, n.d.), p. 26.

${ }^{39}$ Leon Trotsky on Black Nationalism, p. 26.

${ }^{40}$ Ibid., pp. 24, 25.

11 Ibid., p. 51 .

42 Ibid., p. 52.

43 The Balance Sheet, p. 12.

44 'The Revolutionary Solution to the Negro Problem . . ', op. cit.; for a later statement of James's group on the race question see 'Negro Americans and American Politics', in C. L. R. James, Every Cook Can Govern (Detroit, Correspondence, 1956), p. $19 \mathrm{ff}$.

${ }^{45}$ Marxism and the Intellectuals, p. 29.

${ }^{46}$ Black Power, p. 9. 